\title{
Developing A Cutout Paper Doll Game Model To Improvethe Talking Skills Of 5-6 Years Old Children
}

\author{
Esty Susilowati, Suparno \\ Yogyakarta State University, Indonesia \\ estysusi@gmail.com
}

\begin{abstract}
This study aims to: (1) produce a cutout paper doll game model to improve the speaking skills of children aged 5-6 years at Dharma Siwi Kindergarten and Bhakti Siwi Kindergarten, which qualify for early childhood play models; (2) to determine the effectiveness of the cutout paper doll game model used to improve the speaking skills of children aged 5-6 years in Dharma Siwi and Bhakti Siwi Kindergarten. This study uses a Research \& Development approach. This research procedure uses ADDIE development steps, including (1) Analysis, (2) Design, (3)Development, (4) Implementation, and (5) Evaluations. The subject of the group trial involved 19 children aged 5-6 years and one teacher. The subject of the field trials involved 53 children and four teachers. The data analysis technique used the Wilcoxon test with the help of SPSS 19. The results of this study are (1) the cutout paper doll game model to improve speaking skills of children aged 5-6 years meet the eligibility criteria based on the responses of material experts, media experts, and teachers' responses put it in the Good category; (2) the cutout paper doll game model based on the effectiveness test is proven effective at improving children's speaking skills. This can be seen from the calculation results of Aasymp.Sig. (2-tailed) that is 0.000 less than $<0.05$ so that there is a difference in the children's speaking ability score between the initial and the final ability after being given treatment.
\end{abstract}

Keywords: paper doll unloading game, speaking skills, children aged 5-6 years

\section{INTRODUCTION}

Early childhood is an individual who is undergoing a very rapid process of growth and development. Early childhood development is the mainstay of life for children. Early Childhood Education is an educational forum that has an important role in the development of human resources given to early childhood. In accordance with SISDIKNAS 2003 Article 1, article 14, Early Childhood Education is a coaching effort aimed at children from birth to six years of age, which is carried out by providing educational stimuli to assist physical and spiritual growth and development so that children have the readiness to enter more education. Continue. Early childhood is often referred to as the golden age period, which is a sensitive period so that all potential development can be maximally developed. All children's potential will be able to develop optimally if given the right stimulation according to the child's level of development. Providing stimulation in Early Childhood Education should be carried out comprehensively. That is, providing stimulation must cover all aspects of child development, which include physical motor development, cognitive, language, moral and religious, social, emotional, and art. This development will be optimal if the stimulation process is carried out in a balanced manner. Providing stimulation in Early Childhood Education should be carried out comprehensively. That is, 
providing stimulation must cover all aspects of child development, which include physical motor development, cognitive, language, moral and religious, social, emotional, and art. This development will be optimal if the stimulation process is carried out in a balanced manner. Providing stimulation in Early Childhood Education should be carried out comprehensively. That is, providing stimulation must cover all aspects of child development, which include physical motor development, cognitive, language, moral and religious, social-emotional, and art. This development will be optimal if the stimulation process is carried out in a balanced manner.

Facts in the field show that early childhood, especially those aged 5-6 years, emphasize more on reading and writing preparation and pay less attention to speaking skills. It is important that children's speaking skills be developed optimally in line with other skills. Vygotsky (Wiliam Crain, 2014: 342) argues that mastery of speech or language expressions is very important for children to be able to participate in their social life. Vygotsky also believed that speaking and thinking with the help of words contributed greatly to one's thinking ability. In learning activities, the interactions that occur between teachers and children are a bridge to transmit information or knowledge.

There are various ways that can be done to improve children's speaking skills. one of them is by using play activities. In playing activities, children will be actively involved in learning activities without feeling overwhelmed. Play activities in Early Childhood Education can be designed in such a way as to stimulate children's development and growth. These games can also be called educational games. Educational games, according to Mayke (2001: 81-87), are games that are deliberately designed specifically for educational purposes. One of them is playing a game of loading and unloading paper dolls.

According to Ismail (2009: 199), the loading and unloading game is a game of arranging an object or image that has been separated into several parts and is useful for training children's intelligence. Another opinion expressed by Muzalim (2010: 46) comes from the English puzzle, which means puzzle or unloading, which is a game by being dismantled and installed. The assembling game is a game that involves hand-eye coordination. According to Nani (2008: 31) continues that unloading pairs are one of the games that children enjoy, and aspects that can be developed through unloading games are cognitive, fine motor skills, language, and social-emotional. Dismantling pairs of paper dolls or Papper dolls is a game of assembling pairs using paper doll media..

\section{THEORETICAL PERSPECTIVES}

Experts say that the world of children is a world of play. Playing is an activity that is a characteristic that is usually done by children. Playing has a very important meaning for children, every healthy child always has the urge to play. Playing is an activity that can cause feelings of pleasure. Playing, according to Hurlock (1978: 320), is an activity that causes pleasure without thinking about the impact it will have. In line with that, according to Santrock (2002: 16), playing is a fun activity carried out for the benefit of the activity itself. Early childhood need play to start interacting with their environment. Ginsburk (2007: 188) says that playing is a valuable part of childhood that provides benefits for children's development. Mukherji \& Louise (2014: 125) also argue that playing provides opportunities for children to develop all skills related to social, physical, intellectual, and language development. Papalia (1986: 233) explains that through children's play to grow, they learn how to use their muscles, learn to coordinate what they see and what they do, and they learn to control their bodies, they find out about how the world is. This and how their world is. They acquire new skills and learn to use them. They try various aspects of life. They overcome their emotional conflicts and re-enact them in real life. An activity can be categorized as a play activity if it has certain characteristics or criteria. Menutut Seifert \& Hoffnung in Harun (2012: 67) interpret play if the game has six elements, namely; (1) benefits children; (2) oriented to the activity process; (3) please the child; (4) different from reality; (5) have flexible rules; (6) children are directly involved. Furthermore, Harun explained that the concept of play raises two 
views, namely, playing for fun and playing with win-lose. Playing to seek pleasure in the sense of play is an activity to really get pleasure psychologically through physical activity. Meanwhile, playing for fun followed by win-lose in the sense of a game means involving other people.

Ismail (2006: 17) suggests some of the benefits of playing; (1) channeling the excess energy of the child; (2) means to prepare for his life in the future; (3) continuing the image of humanity; (4) build up lost energy; (5) obtaining the compensation that is not obtained, (6) releasing feelings and emotions; (7) provide a stimulus for a personality formation. Play activities in Early Childhood Education can be designed in such a way as to stimulate children's development and growth. These games can also be called educational games. Educational games usually use tools called educational games (APE). Some educational play tools are manipulative tools that can be used skillfully, according to the wishes and imagination of the child. APE is usually designed in such a way as to be used as a play activity that stimulates aspects of child development. According to Surtikanti (2011: 103), playing tools are all kinds of means that can stimulate activities that make children happy, while educational game tools are play tools that can improve entertaining and educational functions. So it can be concluded that educational game tools are anything that can be used as a means or equipment for a play that contains educational value and can develop all aspects of child development.

According to Ismail (2009: 199), the loading and unloading game is a game of arranging an object or image that has been separated into several parts and is useful for training children's intelligence. Another opinion was expressed by Muzalim (2010: 46) that the unloading comes from the English language puzzle, which means a puzzle or unloading, which is a game by being dismantled and installed. The assembling game is a game that involves hand-eye coordination. Furthermore, Muzalim (2010: 78) continues that there are various kinds of loading and unloading games, namely loading and unloading construction, unloading floors, unloading letters, unloading pairs of fruits, unloading pairs of paper, unloading pairs of animals, unloading pairs of jiksaw, and many others. The loading and unloading game is one of the educational games because through this game, it can develop various aspects of child development, children are actively involved in games, and are constructive. According to Necpeca (2012: 3) states that constructive play is a variety of activities carried out by building and making something, constructing large objects from small objects, and making something that can be reused after the child has finished playing. Playing constructing can also be referred to as a game of compiling, dismantling, and installing. The game of dismantling paper dolls or Papper dolls is a game of dismantling and installing using paper doll media. The game of unloading pairs of paper dolls is considered to be able to develop children's speaking skills because children can dialogue by playing roles using paper dolls. Children can imagine, according to the paper doll they play with. The game of unloading pairs of paper dolls can be adopted in play activities that can be applied in the early childhood learning process. The game of unloading pairs of paper dolls that will be applied in early childhood learning should meet the criteria for early childhood learning. Therefore, it is necessary to have an innovation to develop a game of loading and unloading paper dolls, which is usually an educational game of unloading pairs of paper dolls. The game of unloading pairs of educational paper dolls is a game that has an educational purpose. One of the goals that can be achieved is to improve early childhood speaking skills.

Musfiroh (2017: 15-17) explains his observations about psycholinguistics and divides language acquisition into two processes, namely the language acquisition process, and the language learning process. Brooks (2012: 9) states that children will understand knowledge about the environment, culture, and nature through interaction and communication. Children seek knowledge by interacting with objects and people around them. One form of interaction or communication is talking. Cunningham \& Edmonds (Chris Valeska, 2012: 9) states that speaking is more than just producing words. Speaking is a more complex skill that involves multiple actions, such as turn-taking, questioning, the use of adequate 
pressure, and intonation. This means speaking is not just saying a sound of words, but in speaking, activities involve a lot of action. Suhartono (2005: 21) states that speaking is a form of human behavior that utilizes physical, psychological, neurological, semantic, and linguistic factors. First, physical factors, namely the tools of speech to produce language sounds, such as head, hands, and facial features that are used in speaking. Second, psychological factors can affect speaking fluency. Emotional stability not only affects the sound quality but also affects the convolution of the material. Third, neurological factors, namely the neural network that connects the cerebellum to the mouth, ears, and other organs that participate in speaking activities. Fourth, semantic factors are related to the meaning of a spoken word. Fifth, linguistic factors are related to the structure of language. The resulting sound must be arranged according to certain rules to be meaningful. If the words arranged do not follow the rules of language, it will affect the understanding of the meaning by the interlocutor. Donoghue (2009), Strickland, Galda \& Cullinan, and also Burhan mentioned several strategies for teaching children's speaking; (1) discussion; (2) interview/question and answer; (3) telling stories; (4) presentation; (5) drama; (6) conference; (7) speaking with visual, audio, audio-visual stimuli. Some of these strategies can be used to improve children's speaking skills. The development of early childhood speaking skills with these various strategies should be packaged in an interesting and fun activity. One of them is packed in playing activities using games. The game that can be done is the game of assembling paper dolls that have been developed so that it can be done by early childhood. Djiwandono in (Halida, 2011: 6) that speaking ability is a verbal self-disclosure. Linguistic elements that can support the effectiveness of speaking, namely (1) clear pronunciation; (2) reasonable intonation; (3) the right choice of words; and (4) applying the correct sentence structure/composition. The non-linguistic aspect is the factors outside the linguistic element that support the ongoing speaking activity, which can be categorized as non-linguistic factors, namely: (1) courage; (2) fluency; (3) body expressions/movements. These aspects of speaking skills are a developmental task that every child must pass and develop. Teachers need to provide services that can stimulate these aspects of speaking skills.

\section{Research Method}

This study uses research and development using the ADDIE model. Branch (2009: 2) states that ADDIE stands for Analyze-Design-Development-Implementation-Evaluation. Sezer, et al. (2013: 137) states that: "ADDIE is the system approach implies an analysis of how its competents interact with each other and required coordination of all design, development, implementation and evaluation activities". That is, ADDIE is a systems approach that implies an analysis of its components interacting with one another and requires coordination of all design, development, implementation, and evaluation activities. The ADDIE model development research is an attempt to produce or develop a particular product. This research is focused on developing a paper doll unloading game model to improve the speaking skills of children aged 5-6 years. The ADDIE model uses five stages of development, namely:

1. Analysis is a step to analyze needs, identify problems, identify products that are in accordance with targets, and thoughts about the products to be developed.

2. Design is the design stage of the product concept to be developed.

3. Development is a step to transform the design into a real product.

4. Implementation is a product trial as a concrete step in implementing the products that have been made.

5. Evaluation is a process to see whether the product is successful or as expected.

Research is a type of research and development using the ADDIE model. The subjects of the effectiveness test in this study were 53 children aged 5-6 years in TK Dharma Siwi and TK Bhakti Siwi. The data collection instruments used interview guidelines, questionnaires, and observation sheets. Interviews were conducted to gather information related to the process of developing children's 
speaking skills, which is usually done by teachers. The questionnaire was used to see the feasibility of the paper doll unloading game model using the Likert scale. Observations were made to see the child's speaking skills.

The effectiveness test in this study used the pre-experimental research method in the form of a onegroup pretest-posttest design only.

\section{$\mathrm{O} 1 \mathrm{X} \mathrm{O} 2$}

. One Group Pretest Posttest Design (Sugiyono, 2015: 111)

$01=$ pretest value (before being given treatment)

$\mathrm{O} 2=$ posttest value (after being given treatment)

$\mathrm{X}=$ treatment with unloading paper dolls.

\section{FINDINGS AND DISCUSSION}

Speaking skills are an important skill to develop in balance with other skills in aspects of language development. Brooks (2012: 9) states that children will understand the knowledge of the environment, culture, and nature through interaction and communication. Children seek their knowledge by interacting with objects and people around them. One form of interaction or communication is speaking. Musfiroh (2017: 15-17) explains his observations on psycholinguistics and divides language acquisition into two processes, namely the language acquisition process, and the language learning process. Humans not only acquire language, but language ability can also be developed through practice through learning so that there are differences in outcomes or developmental achievements.

Play and games become one of the activities done in early childhood learning. So that the game can be designed in such a way that it can be used as stimulation of child development, this study develops a model of unloading paper dolls to improve the speaking skills of 5-6-year-olds. Development was done using ADDIE model development research. The results of the development of the game model of unloading paper dolls and implementation manuals that have been improved during the development process both during the validation phase up to the effectiveness test, the product specifications developed are as follows:

\section{Unloading game of paper dolls}

In accordance with the opinion of experts on how the development of speaking skills concluded that to improve children's speaking skills is by; (a) discussion; (b) interviews; (c) storytelling; (d) presentation; (e) drama; (f) conferences; (g) speak with visual, audio, audio-visual stimuli. Based on the opinion of these experts, then the researchers look for some games that are assessed to improve children's speaking skills and adapted to the criteria mentioned by experts. The unloading game of selected paper dolls should meet at least half of the above seven criteria. In the game of unloading paper dolls is assessed to meet the elements: (a) discussion, where the child can discuss with his opponent about the roles that will be performed using paper doll media; (b) interview (question and answer), the child can ask questions with his playmate related to the theme of the profession he plays, for example when playing the profession the pediatrician will ask questions to the patient he examines; (c) storytelling, the child can tell the story in accordance with the dialogue he created himself through the paper doll he played with his teacher and classmates; (d) drama, the child can play a drama or play a role with a dialogue he created himself with his playmate; (e) speaking with visual stimuli, the child will be 
able to speak or dialogue with several visual stimuli or images that are different from some image choices on the theme of the profession.

In the implementation of the game of unloading paper dolls, then it is necessary to plan play activities. In accordance with the syntax of the implementation of games in early childhood learning are:

a. Designing play activities (planning)

In designing play activities, it is necessary to determine the purpose, the purpose of the implementation of this paper doll unloading game is to develop aspects of child development, especially on the speaking skills of children aged 5-6 years. The activity performed is that the child will play unloading using paper dolls with a professional theme with four kinds of professional choices, namely doctors, teachers, chefs, and police. Play activities can be done in the classroom by dividing the children into four groups. Play activities can be done individually or in groups. The steps are as follows:

b. Implementation

1) Preparation

a) Teacher prepares classroom or hall for the playground.

b) Teacher prepares supportive game equipment in play activities.

2) Equipment

a) Paper dolls with a professional theme (doctors, teachers, chefs, and police).

3) Game Procedures

a) Pre-play / pre-play activities

i) divide the child into four groups.

ii) introduce various professions in the game of unloading paper dolls (doctors, teachers, chefs, and police).

iii) invite the child for discussion to determine or choose the sub-theme of the profession that will be done in each group.

iv) provide initial information about roles in the profession (doctors, teachers, chefs, and police).

v) allow the child to play in accordance with the role of the paper doll that the child chooses.

b) Play activities

i) the child plays a game of unloading paper dolls.

ii) the teacher observes the child's activities.

iii) teachers motivate children.

c) Closing activities

i) The teacher invites the child to rearrange the toys that have been used.

ii) teachers dig information about play activities to children.

4) Evaluation

a) teachers prepare assessment instruments for children.

b) the teacher assesses the child's speaking skills.

\section{Unloading game media install paper dolls}

The game of unloading paper dolls that have been set to be developed requires supporting media that are considered suitable for use by children aged 5-6 years. Paper doll media is a supporting media in the game of unloading paper dolls. According to experts, choosing a child's toy should meet some elements. The elements contained in the paper doll media in this study are:

a. A tool that can attract the attention of children, paper dolls in this game of unloading paper dolls can be played by all children (girls and boys) and printed using ivory paper with glossy 
laminate and with bright colors. The shape of the paper doll is not too small and not too big. Paper dolls have several image elements, namely human images, clothing images, and pictures of supporting objects according to each theme.

b. Paper dolls are multi-purpose materials/media, where paper dolls can be used for entertaining and educational purposes. Paper dolls can be used to develop aspects of child development, one of which is to improve children's speaking skills.

c. Paper dolls can give children the opportunity to use in a variety of ways, namely by unpacking and pairing between professional pictures in accordance with the clothes and tools used, children can also use cardboard dolls to play a role according to the theme on paper dolls.

\section{3. implementation handbook}

a. The implementation of the handbook is used as a companion in explaining the activities of unloading the paper doll unloading game developed.

b. Implementation handbook uses language that is easy to understand, so it makes it easier for readers to understand the contents of the handbook.

The results of the group test involving one teacher and 19 students at Kindergarten Songgo Buono got eligible categories and showed that $92.10 \%$ of 19 children could do and are interested in playing unloading paper dolls.

The results of the field test involving four teachers and 53 students in group B. The results of the practitioner test score $63,63,63$, and 64 with the conversion result with an average value of 63.25 so as to enter the criteria "very Good". The results of the Pretest and post-test of students in TK Dharma Siwi and TK Bhakti Siwi were then analyzed with wilcoxon test using SPSS 19. Thus the results of wilcoson test:

Table 1. Wilcoxon Signed Ranks Test TK Dharma Siwi

\begin{tabular}{|l|l|r|r|r|}
\hline \multicolumn{5}{|c|}{ Ranks } \\
\hline
\end{tabular}

The table shows that the value of the negative rank or difference (negative) between the pretest and posttest results is 0 . The value of 0 indicates that there is no decrease from the pretest value to the posttest value. On the positive data, rank or difference (positive) between the results of the pretest and posttest is 25 . This means that 25 children experienced an increase in the results of pretest and posttest from the application of unloading paper dolls. The average increase is 13.00 , while the number of positive rankings is 325.00 . Ties or similarity of pretest and posttest values is 0 , so it can be said that there is no equal value between pretest and posttest. Thus the output of test statistics:

Table 2. Test Statisticsb TK Dharma Siwi

\begin{tabular}{|l|r|}
\hline & Post Test - Pre Test \\
\hline$Z$ & $-3.843 \mathrm{a}$ \\
\hline Asymp. Sig. (2-tailed) & .000 \\
\hline
\end{tabular}


Based on the "test statistics" output it is known that Aasymp.Sig. (2-tailed) is worth 0.000 less than $<0.05$.

Table 3. Wilcoxon Signed Ranks Test TK Bhakti Siwi

\section{Ranks}

\begin{tabular}{|l|l|r|r|r|}
\hline & & \multicolumn{1}{|c|}{$\mathrm{N}$} & Mean Rank & \multicolumn{1}{c|}{ Sum of Ranks } \\
\hline Post Test - Pre Test & Negative Ranks & $0 \mathrm{a}$ & .00 & .00 \\
\cline { 2 - 6 } & Positive Ranks & $28 \mathrm{~b}$ & 14.50 & 406.00 \\
\cline { 2 - 6 } & Ties & $0 \mathrm{c}$ & & \\
\cline { 2 - 6 } & Total & 28 & & \\
\hline
\end{tabular}

The table shows that the value of the negative rank or difference (negative) between the pretest and posttest results is 0 . The value of 0 indicates that there is no decrease from the pretest value to the posttest value. In the positive data rank or difference (positive) between the results of the pretest and posttest is 28 . This means that 28 children experienced an increase in the results of pretest and posttest from the application of unloading paper dolls. The average increase is 14.50 , while the number of positive rankings is 406.00 . Ties or similarities of pretest and posttest values are 0 , so it can be said that there is no equal value between pretest and posttest. Thus the output of test statistics:

Table 4. Test Statisticsb TK Bhakti Siwi

\begin{tabular}{|l|r|}
\hline & Post Test - Pre Test \\
\hline$Z$ & $-4.695 \mathrm{a}$ \\
\hline Asymp. Sig. (2-tailed) & .000 \\
\hline
\end{tabular}

Based on the "test statistics" output it is known that Aasymp.Sig. (2-tailed) is worth 0.000 less than $<0.05$.

Based on experiments from product development in the form of the development of a paper doll unloading game model to improve the speaking skills of children aged 5-6 years shows that the paper doll unloading game can improve children's speaking skills. Based on the results of the pretest and posttest of both schools involving 53 children aged 5-6 years Aasymp.Sig. (2tailed) worth 0,000 less than $<0.05$ so it can be concluded that "hypothesis accepted". This means that there is a significant difference in speaking skills between the value of the child's initial ability and the child's final ability after treatment.

\section{CONCLUSION}

The development paper doll unloading game is a paper doll unloading game model that can be used to improve speaking skills in children aged 5-6 years, so it can be argued that:

1. The need for the development of the game of assembling pairs of dolls is to determine the concept of the game, approach methods, equipment, procedures, and production.

2. The game model for unloading pairs of paper dolls that is suitable for children aged 5-6 years to improve their speaking skills is a game model that children can do directly, can provide opportunities for children to be active in communicating or talking, using appropriate and safe supporting media for children, and has the effectiveness according to the expected goals. For valid material and media experts, the game of loading and unloading the development paper dolls got a good category. Whereas in the results of the validation by the loading game, the paper is used to improve the speaking skills of children aged 5-6 years.

3. The results of the test of the effectiveness of developing the paper doll unloading game model are declared effective for improving children's speaking skills. This can be seen 
from the calculation results of Aasymp.Sig. (2-tailed) is 0.000 less than $<0.05$, so it can be denied that it is "accepted". This means that there is a significant difference in speaking skills between the child's initial ability value and the child's final ability after being given treatment.

\section{REFERENCES}

Branch, Maribe Robert. (2009). Intructional Design: The ADDIE Approach. USA: University Of Georgia.

Brooks, Patricia J. Et al. (2012). Language Development. Edition: 1st. Wiley Blackwell. ISBN: 978-14443-3146-2.

Crain, Wiliam. (2014). Teori Perkembangan (Konsep dan teori). Yogyakarta: Pustaka Pelajar.

Ginsburk, Kenneth R. (2007). The Importance of Play in Promoting Healthy Child Development and Maintaining Strong Parent-Child Bond. American Academy of Pediatrics.

Ismail, Andang. (2006). Education Game: Menjadi Cerdas dan Ceria dengan Permainan Edukatif. Yogyakarta: Pilar Media.

Santrock, John W. (2007). Perkembangan anak. Jakarta: Erlangga.

Mukherji, P. \& Dryden, L. (2014). Foundations of early childhood: Principle and practice. London: Sage Publications Ltd.

Musfiroh, Tadkiroatun. 2015. Bermain dan Permainan Anak. Tangerang Selatan: Universitas Terbuka.

Muzamil, Misbach. 2010. Sejarah Indonesia: Media Puzzle. Diunduh pada tanggal 3 Juli 2019 dari http://academia.edu/9717051/.

Nani. 2008. Macam-macam Media Pembelajaran Interaktif. Jakarta: PT Gramedia Pustaka Utama.

Rasyid, Harun, dkk. 2009. Asesmen Perkembangan Anak Usia Dini. Yogyakarta: Multi Pressindo.

Papalia, Diane E. Et.al. (1986). Human Development.New York: McGraw-Hill.

Sugiyono, 2015.Metode Penelitian Pendidikan Pendekatan Kuantitatif, Kualitatif, dan R\&D. Bandung: Alfabeta, cv.

Suhartono. (2005). Pengembangan Keterampilan Bicara Anak Usia Dini. Jakarta: Depdiknas. 